\title{
Advancing the Frontier of Peacekeeping Research
}

Theodora-Ismene Gizelis

Department of Government

University of Essex
Michelle Benson

Department of Political Science

SUNY Buffalo

UN peacekeeping missions have evolved from the small missions of barely 300 personnel in the wake of WWII to the large comprehensive missions with more than 20,000 military personnel and complex mandates. Peacekeepers are now deployed into challenging situations involving intra-state protracted conflicts in institutionally weak states. They are also given broader and more comprehensive mandates to complete a wide range of tasks involving local actors both at the elite and the grassroots levels. Whereas originally peacekeeping aimed to secure the objectives of the major powers - that is, the Permanent Five of the UN Security Council - and national elites, its focus now firmly includes civilians caught up in the fighting and suffering the consequences of poorly governed or failed states. In effect, this has raised the bar for peacekeeping.

In light of the increased expectations of what constitutes a successful UN peacekeeping mission, what evidence exist to support the belief that peacekeeping is an effective tool of conflict resolution? Given the complexity of contemporary missions, we may have expected peacekeeping to fail more often. Indeed, the conventional wisdom is that UN is ineffective.

A growing body of research has aimed to address this issue (Diehl 1993, Diehl and Druckman 2010). The early literature on UN peacekeeping was largely (comparative) case studies examined the legal framework of peacekeeping and the management of peacekeeping operations (Durch et al. 2003; Paris 1997, 2004). Much of this work used UN operational criteria as the yardstick by which to judge 
effectiveness—such as mission mandates, deployment times, and financial and material support (Pushkina 2006, Howard 2008).

Later, quantitative work moved beyond these criteria to examine how UN peacekeeping missions affect long-term outcomes. While some studies were pessimistic about UN effectiveness on the reoccurrence of conflict (e.g., Diehl, Reifschneider, and Hensel 1996), others found encouraging results under specific circumstances (Doyle and Sambanis 2000, 2006) or when selection effects and conflict attributes taken into account (Fortna 2003, 2004, 2008a, 2008b, Gilligan and Sergenti 2008).

More recent work has refined our conceptions of UN peacekeeping effectiveness even further. This new research has largely focused on how UN peacekeeping missions might address urgent, ongoing conflict attributes as well as other immediate conflict outcomes. The ability of the UN to successfully save lives during violence and to limit the diffusion of conflict has been the focus of a growing body of empirical research (Gizelis et al 2016; Goldstein 2011). Hultman, Kathman, and Shannon $(2013,2014)$ show that peacekeepers protect civilians against oneside violence highlighting the increasingly humanitarian role of peacekeepers. Increasing availability of data with detailed information on deployment and activities of peacekeepers has encouraged researchers to examine their impact subnationally. Ruggeri, Dorussen, and Gizelis $(2016,2017)$ show that robust peacekeeping limits the conflict episodes in specific localities, while Gleditsch and Beardsley (2015) demonstrate how peacekeeping can contain conflict from spreading geographically and engulfing countries.

In effect, much of this literature suggests that peacekeeping 'works' if it contributes to a negative peace, where peace is simply the absence of conflict. In 
short, in the empirical literature, peace is often simply defined as a situation without battle related deaths (Gizelis et al 2016, Diehl 2016). ${ }^{1}$ The papers in this special feature expand the bounds of the quantitative literature by examining how UN peacekeeping might affect different forms of violence (Hultman and Johansson) as well as specific forms of peace (Benson and Kathman). The research presented here further examines how different attributes of peacekeeping missions (beyond the number of military troops) can affect the ability of the UN to reduce conflict violence (Bove and Ruggeri and Beardsley, Cunningham, and White). In short, taken together, these articles present a sharp focus on some novel, attributes of the peacekeeping mission as well as an expansion of the understanding of the potential, positive effects of such missions.

Hultman and Johansson in their article 'Credible deterrence? Peacekeeping Responses to Violence against civilians' present one of the very first empirical studies that examine if peacekeeping missions can effectively protect civilians from other forms of atrocities besides one-sided massacres. Current research on sexual violence and UN peacekeeping missions casts serious doubts about the ability of the UN to address sexual violence and other forms of crimes against civilians. Reports of sexual violence and exploitation by peacekeepers further undermine trust in the institution to protect civilians (Higate 2007; Karim and Beardsley 2016; Nordås and Rustad 2013)

Hultman and Johansson argue that there is very limited knowledge on the effects of international strategies for dealing with sexual violence. An additional challenge is the private nature of the sexual violence that makes reporting and detection even harder. Yet, Hultman and Johansson using large-n data on sexual violence find that

\footnotetext{
${ }^{1}$ For a detailed discussion of negative piece, see Diehl (2016).
} 
peacekeepers might be more effective in tackling sexual violence if the missions have stronger mandates on the protection of civilians and the conflict patterns allow local rebel and government leaders to have control over their forces. Furthermore, using data on all armed intrastate conflicts from 1989 until 2009, Hultman and Johansson find that strong mandates are not sufficient to improve the performance of UN missions in reducing sexual violence. The personnel composition of UN missions can also make a difference since UN Police forces might have a comparative advantage over military troops or observers. Overall, the UN seems to perform better when dealing with actors, both governmental and rebel forces, with higher organizational capacity and control over their forces than in dealing with actors with lower organizational capacity.

Does the composition of missions impact the ability of peacekeepers to interact with local actors and citizens? In the article on "The horizontal dimension of peacekeeping: Blue helmets and the locals," Bove and Ruggeri explore whether cultural affinity between peacekeepers and local populations improves the ability of peacekeepers to perform their mandated tasks. The authors start with the assumption that communication and interactions might be more difficult when soldiers are culturally distant from local communities. Yet, their research suggests that greater cultural distance, measured by the weighted distances between the country of origin of peacekeepers and the host country, are associated with lower levels of battle deaths and lower levels of violence against civilians. Their findings build on a new body of literature that explores the types of interactions between peacekeepers and local populations, including the formation of unequal transactional relationships. In these cases, closer cultural proximity creates more opportunities for 
such relationships to emerge rather than situations where peacekeepers are distant or perceived as neutral (Beber et al 2017).

Combined, the two articles pose important questions about our understanding of the role the UN can play in post-conflict reconstruction and how the composition of missions, both in types of personnel and the ethnic diversity of personnel, can impact effectiveness of missions. Increasingly research highlights the role of UNPOL more than military troops in improving living conditions for civilians. Yet, much research either lumps together UNPOL and the military or focuses on the presence or size of the aggregate UN force (e.g., Doyle and Sambanis 2000; Fortna 2008a; Gilligan and Sergenti 2008). Furthermore, the ethnic composition of the missions might have a significant impact on their effectiveness to connect with local populations. Yet, the findings are counter-intuitive with significant policy implications regarding ideal contributor countries for different conflicts.

In a similar vein, Benson and Kathman examine troop variation in their article "The Effects of Troop Variation and Bias on UN Peacekeeping Success." Here, Benson and Kathman are primarily interested in fine-grained variations in deployment numbers and their impact on the effectiveness of missions to lead to peaceful outcomes. The monthly-level data allow the authors to map, in detail, changes in personnel levels and how such changes correspond to ever changing conflict dynamics. Instead of focusing on negative peace, the authors examine how properly outfitted UN peacekeeping operations lead to a quicker, peacefully negotiated settlement outcomes versus outright military victories or conflicts that fizzle out. 
Their study is further corroborated by the Beardsley, Cunningham, and White paper on 'UN Engagement and the Severity of Conflict.' Beardsley et al. also use monthly-data on peacekeeping deployment and reach conclusions that parallel Benson and Kathman in linking peacekeeping to mediation attempts. The literature often assumes that peacekeeping forces are deployed after a peace agreement has been reached to maintain the peace. Beardsley et al challenge this sequential and static view of different methods of conflict management. Their study suggests that mediation and peacekeeping are not two separate, independent processes of conflict management, but often occur simultaneously or in quick succession. Even more important, mediation efforts reveal information that allow for partial peace agreements that subsequently lead to the deployment of peacekeeping forces. While their study provides further support that larger UN missions are effective in reducing battle-deaths, they also argue that conflict management methods should be assessed for their overall effect on creating opportunities for cooperation rather being evaluated using reduction of battle deaths as the sole criterion.

Combined, the four articles contribute to the literature on peacekeeping and conflict management in three ways: (1) Further provide evidence that deploying robust peacekeeping forces reduce the levels of battle deaths, and under certain circumstances even other forms of violence such as sexual violence and rape. The effect on sexual violence is far more limited in scope and magnitude compared to the reduction of battle-deaths. Yet, the Hultman and Johansson study is the first to show that the UN deployment can have a positive effect in reducing sexual violence but under very specific conditions. (2) Expand the research agenda by highlighting the importance of disaggregating UN forces in terms of composition. When it comes to the composition, both the ethnic characteristics of peacekeepers and their roles in 
the mission are important in shaping the interactions between peacekeepers and local actors. (3) Use fine-grained, monthly-level, disaggregated UN troop-type deployment data to study how robust peacekeeping can lead to reduced battlefield violence and faster, peaceful ends to conflicts. Taken together, this work supports the idea that the positive outcomes of UN peacekeeping are not limited to postconflict interventions to keep the peace (Gilligan and Sergenti, 2008). In summary, and in the aggregate, each of these papers points to the promise of robust and properly outfitted UN peacekeeping operations to help bring about better outcomes in the different stages of conflict. 


\section{$\underline{\text { References }}$}

Beardsley, Kyle and Kristian Skrede Gleditsch. 2015. “Peacekeeping as Conflict Containment." International Studies Review. 17(1): 67-89.

Bernd Beber, Michael Gilligan, Jenny Guardado, and Sabrina Karim. 2017. Peacekeeping, International Norms, and Transactional Sex in Monrovia, Liberia. International Organization 71(1): 1-30.

Diehl, Paul. 1993. International Peacekeeping. Baltimore, MD: Johns Hopkins University Press.

Diehl, Paul. 2016. Exploring Peace: Looking Beyond War and Negative Peace. International Studies Quarterly 60(1): 1-10.

Diehl, Paul and Daniel Druckman. 2010. Evaluating Peace Operations. Boulder, CO: Lynne Rienner.

Diehl, Paul, Jennifer Reifschneider and Paul Hensel. 1996. “United Nations Intervention and Recurring Conflict." International Organization 50(4): 683-700.

Doyle, Michael and Nicholas Sambanis. 2000. "International Peacebuilding: A Theoretical and Quantitative Analysis." American Political Science Review 94(4): 779-801.

Doyle, Michael and Nicholas Sambanis. 2006. Making War and Building Peace: United Nations Peace Operations. Princeton, NJ: Princeton University Press.

Durch, William J., Victoria K. Holt, Caroline R. Earle, and Moira K. Shanahan, 2003. The Brahimi Report and the Future of Peace Operations. Washington, DC: Stimson Center. Fortna, Virginia Page. 2003. "Scraps of Paper? Agreements and the Durability of Peace." International Organization. 57(2): 337-372. 
Fortna, Virginia Page. 2004. “Does Peacekeeping Keep Peace? International Intervention and the Duration of Peace After Civil War." International Studies Quarterly 48(2): 269292.

Fortna, Virginia Page. 2008a. Does Peacekeeping Work? Shaping Belligerents' Choices after Civil War. Princeton, NJ: Princeton University Press.

Fortna, Virginia Page. 2008b. "Peacekeeping and Democratization" in From War to Democracy: Dilemmas of Peacebuilding, eds. Anna Jarstad and Timothy Sisk. New York, NY: Cambridge University Press.

Gilligan, Michael and Ernest Sergenti. 2008. “Do UN Interventions Cause Peace? Using Matching to Improve Causal Inference." Quarterly Journal of Political Science 3(2): 89122.

Gizelis, T-I., Dorussen, H. and Petrova, M., 2016. Research Findings on the Evolution of Peacekeeping. In: Oxford Research Encyclopedia of Politics. Editors: Thompson, WR., . Oxford University Press.

Goldstein, Joshua S. 2011. Winning the War on War. Hialeah, FL: Dutton.

Higate, Paul. (2007) Peacekeepers, Masculinities, and Sexual Exploitation. Men and Masculinities 10(1):99-119.

Howard, Lise. 2008. UN Peacekeeping in Civil Wars. New York, NY: Cambridge University Press.

Hultman, Lisa, Jacob Kathman and Megan Shannon. 2013. “United Nations Peacekeeping and Civilian Protection in Civil War." American Journal of Political Science.

Hultman, Lisa, Jacob Kathman and Megan Shannon . 2014. “Beyond Keeping Peace: United Nations Peacekeeping Effectiveness in the Midst of Fighting. " American Political Science Review 108(4): 737-753. 
Karim, S. and Beardsley, K., 2017. Equal Opportunity Peacekeeping. Oxford, UK: University of Oxford Press.

Ragnhild Nordås \& Siri C. A. Rustad. 2013. "Sexual Exploitation and Abuse by Peacekeepers: Understanding Variation." International Interactions. 39:4, 511-534.

Paris, Roland. 1997. "Peacebuilding and the Limits of Liberal Internationalism." International Security. 22(2): 54-89.

Paris, Roland. 2004. At War's End: Building Peace After Civil Conflict. Cambridge, Cambridge University Press.

Pushkina, Darya. 2006. “A Recipe for Success? Ingredients of a Successful Peacekeeping Mission." International Peacekeeping, 13(2): 133-149.

Ruggeri, A., Dorussen, H. and Gizelis, T.I., 2016. “On the Frontline Every Day? Subnational Deployment of United Nations Peacekeepers." British Journal of Political Science. 1-21. Ruggeri, A., Dorussen, H. and Gizelis, T.I., 2017. Winning the peace locally: UN peacekeeping and local conflict. International Organization, 71(1), pp.163-185. 